\title{
Regional Input-Output Analysis of A Mega-Event: Possible Impact of EXPO on Izmir Economy
}

\author{
Bir Mega-Olayın Bölgesel Girdi-Çıktı Analizi: EXPO'nun İzmir \\ Ekonomisine Olası Etkisi
}

\author{
Prof. Dr. Osman Aydoğuş - Asst. Prof. Dr. Çağaçan Değer \\ Elif Tunalı Çalışkan - Gülçin Gürel Günal
}

\begin{abstract}
Izmir has lost the bid for EXPO 2020. Izmir's expectations were high, but to the best information of the authors, these expectations were never systematically quantified. This article quantifies the expected expenditures related to a mega event in Izmir due to i) additional hotel constructions, and, ii) arrival of foreign visitors. Then, the effects of these additional expenditures on regional economy are examined through a closed regional I-O model, where closure is due to ens dogenized consumption expenditures. The calculations are based on a regional I-O table of İzmir, available from İzmir Regional Development Agency IZKA. It is observed that constructions related to a mega event require considerable recycling imports, due to scrap metal dependency of metal production.
\end{abstract}

Keywords: EXPO; Mega-Events; Regional Economic Analysis; Input-Output Tables; Impact Analysis

\section{Özet}

İzmir'in EXPO 2020'ye ev sahipliği yapamayacağı kesinleşmiştir. İzmir'in beklentileri yüksekti fakat yazarların bildiği kadarıyla bu beklentiler sistematik olarak sayısallaştırılmamıştı. Bu çalışma ilk olarak İzmir'de EXPO gibi bir mega-olay çerçevesindeki) ek otel inşaatları, ve, ii) yabancı ziyaretçilerin gelişi, çerçevesin- de beklenen harcamaları sayısallaştırmaktadır. Daha sonra, bu ek harcamalarm bölge ekonomisine etkileri, tüketim harcamaları içselleştirilerek kapatılmış bir bölgesel girdi-çıktı modeliyle incelenmiştir. Hesaplamalar İzmir Kalkınma Ajansı (İZKA)'dan temin edilebilen İmir bölgesel girdi-çıtı tablosuna dayanmaktadır. Mega-olayın gerektirdiği inşsatların, metal üretiminin yüksek hurda metal bağımlılı̆̆ından dolayı, önemli geri dönüşüm ithalatı gerektireceği gözlemlenmiştir.

Anahtar Kelimeler: EXPO; Mega-Olay; Bölgesel İktisadi Analiz; Girdi-Çıktı Tabloları; Etki Analizi

\section{Introduction}

Large scale international events such as the Olympics, World Cups, and the EXPO are always expected to contribute positively to an economy. With such expectations, Izmir, Turkey, has bid to host EXPO 2020. Turkey's national statistics institute, TURKSTAT, draws the following picture for Izmir: It is the $3^{\text {rd }}$ biggest city of Turkey, accounting for $6.45 \%$ of value added created in Turkey in 2010. About $5.3 \%$ of Turkey's population lives in Izmir and the region accounts for $5.73 \%$ of the Turkey's employment. Izmir is also a major port city; $5 / 5 \%$ of exports and $4.5 \%$ of imports in 2012 are through Izmir.

Prof. Dr. Osman Aydoğuş, Ege University Faculty of Economics and Administrative Sciences, osman.aydogus@ege.edu.tr Asst. Prof. Dr. Çağaçan Değer, Ege University Faculty of Economics and Administrative Sciences, cagacan@gmail.com Elif Tunalı Çalışkan, Ege University, eliftunalicaliskan@gmail.com Gülçin Gürel Günal, Ege University, gulcngurel@gmail.com 
The bidding process for EXPO 2020 has resulted in late November, 2013, and the result is in favor of $\mathrm{Du}$ bai (United Arab Emirates), rather than Izmir. Previous experience implies that after a brief rest, Izmir is likely to try again. Should Izmir host a mega event such as EXPO, regional and national income are expected to rise. New hotels may be constructed and a large number of visitors are expected. Infrastructure investments that are already underway are expected to be completed sooner. With the EXPO 2020 bid theme focused on health, the city hopes to raise its investment profile and improve its health tourism potential.

The expectations regarding hosting a mega event such as EXPO are high in Izmir (EXPO 2020 Izmir Yonlendirme Kurulu, 2013). However, academic literature on expected effects of EXPO on Izmir region's economy is virtually nonexistent. To the best knowledge of authors, a systematic analysis of the expected effect of EXPO 2020 on Izmir economy is not done. The main contribution of this study is to analyze the effects of a mega event such as EXPO on Izmir's economy. Such a regional analysis has been conducted for the first time in Turkey.

A second contribution is that the expected impact of EXPO is explicitly quantified for the first time; there are expectations but the authors are yet to identify a source that presents the expected impact of EXPO explicitly. Another contribution of this analysis is to provide an example of regional research with inputoutput I-O tables in mega events literature.

Regional I-O analyses of mega events are relatively rare, due to the limited availability of sub-national I-O tables. For Turkey, such an analysis has never been conducted before and is now possible only because 2008 IZKA Izmir Input-Output Table has been prepared by academic staff from Department of Economics, Ege University, with support from IZKA (Izmir Regional Development Agency). Details of the 2008 IZKA Izmir I-O Table are publicly available (Aydogus et.al., 2013). Based on Izmir regional I-O model, two potential effects of the EXPO are investigated in this paper. Firstly, new hotel constructions are expected; their expansionary effects need to be analyzed. Secondly, a large number of visitors are expected during the EXPO 2020. The impact of their tourism expenditures also need to be analyzed.
The underlying 2008 IZKA Izmir I-O Table is available from Izmir Regional Development Agency (IZKA) in 36 sector detail consistent with NACE 1.1 classification. The analysis is conducted through the multipliers calculated from the regional table. Next section briefly reviews the relevant literature. Third section summarizes the I-O model used for the analysis. Section 4 provides calculations on the construction and tourism expenditures expected due to EXPO; then summarizes the results of the I-O analysis. Last section concludes.

\section{Literature Review}

The mega events literature attempts to isolate effects of large scale social events such as major sports events (Lee and Taylor, 2005; Gelan, 2003; Fourie and Santana-Gallego, 2011), and exhibitions (Kim and Chon, 2009). Analysis of mega events generally employs three approaches: i) I-O analysis, ii) cost-benefit analysis, and iii) computable general equilibrium modeling (Andersson, Armbrecht and Lundberg, 2008). The application of I-O analysis on mega events is just one implementation of the I-O modeling approach. The origins of input-output research go back to Wassiliy Leontief's works that led to a Nobel Prize in 1973. Starting with Leontieff and his team at Harvard University, Akhabbar, Antille, Fontela and Pulido (2011) explain how input-output models fared in United States and how the tool of analysis moved to Europe. These models have been used to analyze various topics, among which are quantification of carbon emission effects of production on the environment (Minx, Wiedmann, Wood, Peters, Lenzen, Owen, Scott, Barret, Hubacek, Baiocchi, Paul, Dawkins, Briggs, Guan, Suh and Ackerman, 2009), examination of sectorial energy usage (Lin and Polenske, 1995), identification of key sectors that need to be supported in times of crisis (Luo, 2013), and analysis of interactions between the real and financial sectors (Leung and Secrieru, 2012). Though frequently denoted in terms of value units, input-output tables in quantity units can also be constructed. Labeled as monetary and physical tables, they have been used to examine physical aspects of economic activity like waste management (Dietzenbacher, 2005) with notes of caution on the different effects of using current and constant prices (Dietzenbacher and Temurshoev, 2012). 
Regarding the use of I-O models to analyze mega events; examples exist, but regional examples are relatively few in number. Kim and Chon (2009) employ a national I-O model to analyze the impact of the exhibition industry in Korea. Lee and Taylor (2005) first estimate the expected number of visitors to the FIFA World Cup 2002 held in Korea; then proceed to examine the effect of this event on Korean economy through multipliers calculated from the economy's I-O table. Collins et.al. (2009) examines the environmental impact of the 2004 World Rally Championship, Wales Rally of Great Britain, on the region. Daniels and Norman (2003) use I-O modeling through IMPLAN 2.0 (Minnesota IMPLAN Group, 1998) software to analyze the effects of seven different sports events in South Carolina, USA. An analysis of EXPO on the Silicon Valley (Bay Area Council Economic Institute and Beacon Economics, 2011) and an investigation of the expected effects of an exposition center on Portland Metropolitan Area (Crossroads Consulting Services, 2011) have been performed. Assessing studies on regional impact of mega events, Lee (2006) lists more examples of research along these lines. Following this lead, impact of a mega event such as EXPO is considered in this article.

\section{The Model}

The analysis is based on a one-region static regional I-O model: 2008 Izmir IZKA Regional Input-Output Model (Aydogus et al, 2013). The model is a basic I-O model and is based on the equilibrium condition that regional production in any sector is equal to the sum of final and intermediate demands. It follows Aydogus (2011) and Haydon et al (2013). For an $n$ sector economy in matrix notation:

$\mathbf{X}=\mathbf{A X}+\mathbf{C}_{0}+\mathbf{Z}_{0}+\mathbf{G}_{0}+\mathbf{E}_{\mathbf{0}}{ }^{\mathrm{D}}-\mathbf{M}_{0}{ }^{\mathrm{D}}+\mathbf{N}_{0}{ }^{\mathrm{TR}}$

Column vector $\mathbf{X}$ is $n x 1$ and represents regional production for $n$ sectors. Intermediate uses are summarized by $\mathbf{A X}$ where each element of the $n \times n$ matrix $\mathbf{A}$, $a_{i j}$, represents input purchase of sector $j$ from sector i. Consumption by households is represented by $\mathbf{C}_{0}$, investment demand is $\mathbf{Z}_{0}$, and government (central and local) expenditure is $\mathbf{G}_{0}$. Each of these elements of final demand is $n \times 1$ vectors. $\mathbf{E}_{0}{ }^{\mathbf{D}}$ is exports to other countries and $\mathbf{M}_{0}{ }^{\mathrm{D}}$ is imports from other countries. $\mathbf{N}_{0}{ }^{\mathrm{TR}}$ is net sales from the region, Izmir in this case, to the rest of the country; i.e. rest of Turkey.
For an open I-O model, the practice is to solve Equation 1 for the equilibrium level of output and determine the effects of final demand shocks on output. Adopting an open model enables calculating direct and indirect effects, where indirect effects are due to secondary shock that occur in other sectors of the region.

Alternative is to close the model by endogenising consumption. Any expansion in economic activity would cause the incomes of the consumers to increase. The increases in income would, in turn, induce additional increases in final consumption demand, which would eventually lead to more income. This circular expansion would eventually subside, but the total expansion in a closed model would be higher than the expansion in an open model. More precisely, in a closed model, in addition to direct and indirect effects of a final demand shock, induced effects can also be calculated.

In order to close the model, a household sector is added to the IO table, increasing matrix sizes to $(n+1)$ $x(n+1)$ and vector sizes to $(n+1) x 1$. Row $n+1$ of the intermediate input transactions matrix, $\mathrm{AX}$, now represents income of the household from various sources. Column $n+1$ is consumption from various sectors. The new sector traces income receipt of the household and expenditures of the household. Assuming that these modifications are imposed on Equation 1, solving Equation 1 yields:

$\mathbf{X}^{*}=(\mathbf{I}-\mathbf{A})^{-1} \mathbf{F}_{\mathrm{o}}$

where $\mathbf{F}_{\mathbf{o}}=\mathbf{C}_{\mathrm{o}}+\mathbf{Z}_{\mathrm{o}}+\mathbf{G}_{\mathrm{o}}+\mathbf{E}^{\mathrm{D}}-\mathbf{M}_{\mathrm{o}}{ }^{\mathrm{D}}+\mathbf{N}_{\mathrm{o}}{ }^{\mathrm{TR}}$ final demand. Let $(\mathbf{I}-\mathbf{A})^{-1}$ denote the Leontief inverse. Then, taking the first difference of Equation 2, the changes in output $\left(\Delta \mathbf{X}^{\star}\right)$ caused by exogenous shocks to final demand $\left(\Delta \mathbf{F}_{\mathrm{o}}\right)$ can be calculated:

$\Delta \mathbf{X}^{*}=(\mathbf{I}-\mathbf{A})^{-1} \Delta \mathbf{F}_{\mathrm{o}}$

Given the changes in output and assumption on linearity, the total impact of changes in final demand on labor demand, labor income, indirect taxes on production, and imports can be calculated. For example, the total change in labor demand will be given by the following equation:

$\Delta \mathrm{L}=\mathbf{l} \Delta \mathbf{X}^{*}=\mathbf{l}(\mathbf{I}-\mathbf{A})^{-1} \Delta \mathbf{F}_{\mathrm{o}}$ 
where $\mathbf{l}$ is an $n \times n$ diagonal matrix, whose elements on the main diagonal are direct labor coefficients $\left(l_{j}=L_{j} /\right.$ $\mathrm{X}_{\mathrm{f}}$ ), and off-diagonal elements are 0 . The essence of Equation 4 is as follows: An increase in equilibrium output would require a change in labor demand. Since any output $\mathbf{X}$ is produced by labor demands $\mathbf{L}$, any change in output would trigger a proportional increase in labor demand, where the proportion is the labor coefficient $1_{j}$. Similarly, impact on labor income would then be:

$\Delta \mathrm{W}=\mathbf{w} \Delta \mathrm{L}=\mathbf{w} \mathbf{l}(\mathbf{I}-\mathbf{A})^{-1} \Delta \mathbf{F}_{\mathrm{o}}$

where $\mathbf{w}$ is a $n x n$ matrix whose diagonal elements are sectorial wage rates $\left(\mathrm{w}_{\mathrm{i}}=\mathrm{W}_{\mathrm{i}} / \mathrm{L}_{\mathrm{i}}\right)$ and off-diagonal elements are 0 . Note that $\mathrm{W}_{\mathrm{i}}$ is labor payments by sector $j$. Following this line of thought further;

$\Delta \mathrm{T}=\mathbf{t} \Delta \mathbf{X}^{*}=\mathbf{l}(\mathbf{I}-\mathbf{A})^{-1} \Delta \mathbf{F}_{\mathrm{o}}$

would be the implied impact on net taxes, with $\mathbf{t}$ denoting a $n \times n$ matrix whose diagonal elements are sectorial net tax rates $\left(t_{i}=T_{j} / X_{j}\right)$ and off-diagonal elements are 0 . Finally, impact on imports can be calculated as:

$\Delta \mathrm{M}=\mathbf{m} \Delta \mathbf{X}^{*}=\mathbf{m}(\mathbf{I}-\mathbf{A})^{-1} \Delta \mathbf{F}_{\mathrm{o}}$

with the diagonal elements of the $n x n$ import parameter matrix $\mathbf{m}$ calculated as $\mathrm{m}_{\mathrm{j}}=\mathrm{M}_{\mathrm{j}} / \mathrm{X}_{\mathrm{j}}$.

The implementation of such a model requires the coefficient matrix $\mathbf{A}$ for the economy under consideration. For the İzmir region, such a table is available from İzmir Regional Development Agency, İZKA. The tab- le is one of the outputs of IZKA's preparatory research projects related to 2014-2023 İzmir Region Plan. The 2008 İZKA İzmir I-O Table is available from İZKA's website. Also, the change in final demand in İzmir caused by a mega-event needs to be calculated. Details of the calculation of the change in final demand and results obtained from the analysis are presented in the next section.

\section{Results}

The input-output analysis relies on changes in final demand. In order to examine the effect of hotel construction expenditures and tourism expenditures triggered by EXPO in Izmir, the magnitudes of these expenditures need to be calculated. Then, the effects of these final demand changes on Izmir region are analyzed through multipliers. Results are presented in 2012 Turkish Liras; conversion to US Dollars can be done through $1 \mathrm{TL}=0.55$ US $\$$ (CBRT-EDDS, 2013).

Regarding the construction of new hotels in preparation for a mega event like EXPO; the number of existing hotel beds in Izmir is 39,704 in 2012 (Ministry of Culture and Tourism, 2013). During the application for EXPO 2020, unofficial predictions implied an additional capacity of 15,000 beds to be constructed in Izmir in preparation for EXPO. This capacity increase is assumed to take place in the form of 3 star 100 room hotels, implying the construction of 60 new hotels. Interviews with the construction sector representatives imply that the additional capacity of 15,000 beds will be constructed at a cost of 344 million TLs.

Table 1. Direct Impacts of EXPO Related Construction and Tourism Expenditures (million TL in 2012 prices or people/year for employment effects)

\begin{tabular}{|l|r|r|r|r|r|}
\hline & $\begin{array}{c}\text { Direct Impact } \\
\text { on Production }\end{array}$ & $\begin{array}{c}\text { Direct } \\
\text { Impact on } \\
\text { Labor } \\
\text { Demand } \\
\text { Lempact on } \\
\text { Labor } \\
\text { Income }\end{array}$ & $\begin{array}{c}\text { Direct } \\
\text { Impact on } \\
\text { Impt Taxes }\end{array}$ & $\begin{array}{c}\text { Direct } \\
\text { Impact on } \\
\text { Imports }\end{array}$ \\
\hline $\begin{array}{l}\text { Construction } \\
\text { Sector }\end{array}$ & 344 & 3123 & 57 & 16 & 0 \\
\hline $\begin{array}{l}\text { Hotels and } \\
\text { Restaurants } \\
\text { Sector }\end{array}$ & 670 & 5843 & 45 & 20 & 23 \\
\hline Sum-Total & 1014 & 8966 & 102 & 36 & 23 \\
\hline
\end{tabular}

Source: Authors' own calculations. $1 \mathrm{TL}=0.55$ US\$ for 2012 
This figure is taken as an increase in final demand of the construction sector. In other words, the expected direct expenditure related to new hotel construction is about 344 million TL, or about 189 million US\$.

Regarding tourism expenditures; it is assumed that the additional 15,000 bed capacity will be fully utilized for 180 days, the entire duration of the EXPO. This implies 2.7 million overnight stays. Each overnight stay is assumed to be done by a visitor from abroad. According to TURKSTAT Tourism Statistics (TURKSTAT, 2013), personal expenditures of visitors from abroad per overnight stay is US\$138 in 2012 in Turkey, or 248 TL using exchange rate data from Central Bank's Electronic Data Delivery System (CBRT-EDDS, 2013). This implies a total of 670 million TL additional tourism expenditure due to EXPO in Izmir. This is the expected final demand increase in "hotels and restaurants" sector. In other words, the expected direct expenditure related to expanding tourism is about 670 million TLs, or about 368 million US\$.

Expected direct impacts of new hotel construction expenditures and expanding tourism expenditures on construction, and hotels and restaurants sectors' production, labor demand, labor income, net taxes on production, and imports are summarized in Table 1. Note that direct impacts on labor demand, labor income, net taxes, and imports of the construction expenditures and tourism expenditures are calculated by using relevant direct coefficients from I-O table. Since direct impacts are considered at this point, impacts on production are equal to the expected increases in direct expenditures. With a higher increase in expenditures, hotels and restaurants sector creates higher increases in labor demand and net taxes. But construction creates more labor income.

Next, given these direct impacts in the construction and tourism sectors, total impacts (= direct+ indirect + induced) on regional production, labor demand, labor income, and imports in the Izmir economy are calculated for 36 sectors by using the regional I-O model presented in the previous section. That is; given changes in final demand, $\Delta \mathbf{F}_{0}$, and the coefficient matrix A obtained from the 2008 İZKA İzmir I-O Table, the algebra implied by Equations 3 to 7 is imp- lemented. Equation 3 yields the impact on production, Equation 4 impact on labor demand, Equation 5 impact on labor income, Equation 6 impact on net taxes and Equation 7 impact on imports. Parameters required for these calculations are direct labor coefficient matrix $\mathbf{l}$ for Equation 4, sectoral wage rates matrix $\mathbf{w}$ for Equation 5, net tax rates matrix $\mathbf{t}$ for Equation 6 and import rates $\mathbf{m}$ for Equation 7. All of these can be calculated from 2008 IZKA İzmir I-O Table, for the table includes production, employment, labor payment, net taxes and imports for 36 sectors, facilitating the calculation of impact of changes in final demand. Results for 36 sectors are provided in Appendix Tables 1 and 2 for the construction and tourism expenditures respectively and aggregated results are given below in Table 2.

Table 2 shows that the sum-total production impact of the introduced two final demand shocks amounts to 2.3 billion TLs. Two-third of the total production increase is due to the tourism related expenditures of foreign visitors. Tourism causes higher income generation as well; however, the income generation due to tourism seems relatively less compared to construction. For a production increase of 769 million TL, construction creates 101 million TL additional labor income: a ratio of $101 / 769=0.13$. The same ratio is 0.095 for tourism; construction leads to higher labor income effects.

Construction is also observed to create higher level of imports. This is due to the high import requirement of metal production in Izmir. Metal production uses scrap metal. In Izmir, scrap metal is imported in the form of scrap ships. These ships are brought to Izmir, dismantled and recycled; then used as inputs to metal production. Construction has a high metal requirement in the Izmir region and in Turkey; cement is applied on metal skeletons to construct buildings. Therefore, construction related demand shock causes a high increase in imports.

One of the major advantages of employing a regional I-O model is that detailed sectorial results can be obtained. Total impacts of construction and tourism expenditures on production, labor demand, labor income, net taxes, and imports for 36 sectors are presented in Appendix Tables 1 and 2. 
Table 2. Total Impact of EXPO Related Construction and Tourism Expenditures (million TL in 2012 prices or people/year for employment effects)

\begin{tabular}{|l|r|r|r|r|r|}
\hline & $\begin{array}{c}\text { Total Impact } \\
\text { on Production }\end{array}$ & $\begin{array}{c}\text { Total Impact } \\
\text { on Labor } \\
\text { Demand }\end{array}$ & $\begin{array}{c}\text { Total } \\
\text { Impact on } \\
\text { Labor } \\
\text { Income }\end{array}$ & $\begin{array}{c}\text { Total } \\
\text { Impact on } \\
\text { Net Tax }\end{array}$ & $\begin{array}{c}\text { Total } \\
\text { Impact on } \\
\text { Imports }\end{array}$ \\
\hline $\begin{array}{l}\text { Construction } \\
\text { Expenditure }\end{array}$ & 769 & 5867 & 101 & 35 & 260 \\
\hline $\begin{array}{l}\text { Tourism } \\
\text { expenditures }\end{array}$ & 1543 & 11258 & 148 & 66 \\
\hline $\begin{array}{l}\text { Sum-Total } \\
\text { Change (\%) }\end{array}$ & 2312 & 17125 & 250 & 101 & 409 \\
\hline
\end{tabular}

Regarding the construction of new hotels; highest production impact is on the construction sector itself. The metal input requirement of construction is reflected in the production increase displayed by the "manufacture of basic metals" sector. Greatest increase in labor demand is observed in "construction", followed by "wholesale and retail trade". Related increase in labor income is observed in "construction" and "other services", followed by "wholesale and retail trade". Created tax revenue is expected to be largest in "construction" sector; this is followed by "mining; extraction of petroleum and natural gas".

Highest import effect is on recycling. This is due to the interaction between recycling and metal production. In Izmir, metal production is through scrap metal. Most of the scrap metal is obtained in form of imported old ships that are dismantled in Izmir. Dismantled ships are then used for metal production. Therefore; as construction sector expands, more metal production becomes necessary. This triggers imports of scrap metal accounted under the recycling sector.

As for hotels and restaurants; in addition to service related sectors, considerable production effect in "electricity, gas, steam and hot water production and distribution" sector is observed, most likely due to the power and water requirements of hotels. Highest increases in labor demand are in "hotels and restaurants", trade, and services sectors. Agriculture and "manufacture of food products and beverages" also require more labor to meet the expanding demand in the region. However, these sectors do not appear to create matching increases in labor income; leading sector in this regard is "hotels and restaurants", followed by services and trade.

Highest increase in tax creation is in the "hotels and restaurants" sector. "Agriculture, hunting and forestry" and "land, water, air and pipeline transportation and communication" sectors also create relatively more tax. High recycling import requirement is observed once more.

\section{Conclusion}

This study examines the impact of a mega event like the EXPO in Izmir region of Turkey. Three contributions are made: i) a regional I-O analysis of a mega event in Izmir, or for any region of Turkey, is conducted for the first time; ii) final demand effects of a mega event in Izmir are quantified; iii) a closed regional I-O model is exemplified.

In addition to the sectorial quantified results of the mega event, it is observed that Izmir has a very high recycling import dependency. Any metal demand related final demand shock to the region would trigger high imports. This implies a need for recycling policy at not only the regional level but also the national level.

One of the long term benefits of a mega event in Izmir would be an improvement in infrastructure. But there are also downsides. Any excess supply created during the preparation phase needs to be eliminated after the mega event; otherwise, the region may experience considerable recession. This implies that preparations for a mega event have to include plans for the post-event era as well. 


\section{References}

Akhabba, A., Antille, G., Fontela, E., Pulido, A. (2011). Input-Output in Europe: Trends in Research and Application. MPRA Paper No. 30208.

Andersson, T. D., Armbrecht, J., Lundberg, E. (2008). Impact of Mega-Events on the Economy. Asian Business and Management. 7(2): 163-179. doi:10.1057/ abm.2008.4

Aydoğuş, O. (2011). Girdi-Çıktı Modellerine Giriş, $3^{\text {rd }}$ edition, Ankara: Efil.

Aydoğuş, O., Değer, C., Çalıșkan, E.T., Günal, G. G. (2013). A Regional Input-Output Model for Izmir. Working Papers 1302, Ege University, Department of Economics.

Bay Area Council Economic Institute and Beacon Economics (2011). World Expo 2020 Silicon Valley-USA Economic Impacts. Address: http://goo. gl/ZgRiyS Access Date: 14 August 2013.

CBRT-EDDS (2013). Central Bank of Republic of Turkey Electronic Data Delivery System. Address: http://tinyurl.com/nn8qoc4 Access Date: 4 August 2013.

Collins, A., Jones, C., Munday, M. (2009). Assessing the Environmental Impacts of Mega Sporting Events: Two Options?. Tourism Management. 30(6): 828837. doi: 10.1016/j.tourman.2008.12.006

Crossroads Consulting Services (2011). Portland Metropolitan Exposition Center Economic and Fiscal Impact Analysis FY 2010. Address: http://goo.gl/ X8nO7A Access Date: 20 August 2013.

Daniels, M. J., Norman, W. C. (2003). Estimating the Economic Impact of Seven Regular Sport Tourism Events. Journal of Sport Tourism. 8(4): 214-222. doi: $10.1080 / 1477508032000161528$

Dietzenbacher, E. (2005). Waste Treatment in Physical Input-Output Analysis. Ecological Economics. 55(1):11-23. doi: 10.1016/j.ecolecon.2005.04.009

Dietzenbacher, E., Temurshoev, U. (2012). Input-Output Impact Analysis in Current or Constant Prices: Does It Matter? Journal of Economic Structures, 1(4). doi:10.1186/2193-2409-1-4

EXPO2020 İzmir Yönlendirme Kurulu (2013). EXPO'nun Kazandirdıkları. Address: www.expoizmir.org.tr, Access: 4 August 2013.

Fourie, J., Santana-Gallego, M. (2011). The Impact of Mega-Sport Events on Tourist Arrivals. Tourism Management. 32(6): 1364-1370. doi:10.1016/j.tourman.2011.01.011
Gelanlan, A. (2003). Local Economic Impacts: The British Open. Annals of Tourism Research. 30(2): 406-425. doi: 10.1016/S0160-7383(02)00098-1

Kim, S.S., Chon, K. (2009). An Economic Impact Analysis of the Korean Exhibition Industry. International Journal of Tourism Research. 11(3): 311318. doi: 10.1002/jtr.691

Lee, C.K., Taylor, T. (2005). Critical Reflections on the Economic Impact Assessment of a Mega-Event: The Case of 2002 FIFA World Cup. Tourism Management. 26(4): 595-603. doi:10.1016/j.tourman.2004.03.002

Lee, M. J. (2006). Analytical Reflections on the Economic Impact Assessment of Conventions and Special Events. Journal of Convention and Event Tourism. 8(3): 71-85. doi: 10.1300/J452v08n03_04

Leung, D., Secrieru, O. (2012). Real-Financial Linkages in the Canadian Economy: An Input-Output Approach. Economic Systems Research. 24(2): 195223. doi: 10.1080/09535314.2012.684345

Lin, A., Polenske, K. R. (1995). Input-Output Anatomy of China's Energy Use Changes in the 1980s. Economic Systems Research, 7(1): 67-84. doi: 10.1080/09535319500000011

Luo, J. (2013). Which Industries to Bail Out First in Economic Recession? Ranking US Industrial Sectors by the Power-Of-Pull. Economic Systems Research. 25(2): 157-169. doi: 10.1080/09535314.2013.775111

Ministry of Culture and Tourism (2013). T.C. Kültür ve Turizm Bakanlığı Yatırım ve İşletmeler Genel Müdürlüğü. Address: http://tinyurl.com/pjwekvb Access Date: 4 August 2013.

Minnesota IMPLAN Group. (1998). IMPLAN 2.0(Computer Software). Stillwater. MN: MIG, Incorporated.

Minx, J.C., Wiedmann, T., Wood, R., Peters, G.P., Lenzen, M., Owen A., Scott, K., Barrett, J., Hubacek, K., Baiocchi, G., Paul, A., Dawkins, E., Briggs, J., Guan, D., Suh, S., Ackerman, F., (2009). Input-Output Analysis and Carbon Footprinting: An Overview of Applications. Economic Systems Research. 21(3): 187-216. doi: 10.1080/09535310903541298

TURKSTAT (2013). TURKSTAT Tourism Statistics. Address: www.turkstat.gov.tr Access Date: $4 \mathrm{Au}-$ gust 2013. 


\section{Appendix}

Appendix Table 1. Impact of Hotel Constructions (million TL in 2012 prices or people/year for employment effects)

\begin{tabular}{|c|c|c|c|c|c|c|}
\hline & & $\begin{array}{l}\text { Impact on } \\
\text { Production } \\
\end{array}$ & $\begin{array}{c}\text { Impact on } \\
\text { Labor } \\
\text { Demand } \\
\end{array}$ & $\begin{array}{c}\text { Impact on } \\
\text { Labor } \\
\text { Income } \\
\end{array}$ & $\begin{array}{c}\text { Impact on Net } \\
\text { Tax }\end{array}$ & $\begin{array}{c}\text { Impact on } \\
\text { Imports }\end{array}$ \\
\hline 1 & Agriculture, hunting and forestry & 2.0 & 0.2 & 24 & 0.3 & 0.2 \\
\hline 2 & Fishing & 0.0 & 0.0 & 0 & 0.0 & 0.0 \\
\hline 3 & Mining and quarrying & 30.3 & 3.9 & 107 & 4.4 & 1.7 \\
\hline 4 & Manufacture of food products and beverages & 0.8 & 0.1 & 5 & 0.0 & 0.1 \\
\hline 5 & Manufacture of tobacco products & 0.0 & 0.0 & 0 & 0.0 & 0.0 \\
\hline 6 & Manufacture of textiles and textile products & 0.3 & 0.0 & 3 & 0.0 & 0.1 \\
\hline 7 & Manufacture of wearing apparel; dressing and dyeing of fur & 0.4 & 0.1 & 7 & 0.0 & 0.0 \\
\hline 8 & $\begin{array}{l}\text { Tanning and dressing of leather; manufacture of luggage, } \\
\text { handbags, saddlery, harness and footwear }\end{array}$ & 0.1 & 0.0 & 1 & 0.0 & 0.1 \\
\hline 9 & $\begin{array}{l}\text { Manufacture of wood and products of wood and cork (except } \\
\text { furniture); articles of straw and plaiting materials }\end{array}$ & 4.7 & 0.3 & 74 & 0.2 & 1.0 \\
\hline 10 & Manufacture of pulp, paper and paper products & 2.9 & 0.3 & 16 & 0.1 & 1.2 \\
\hline 11 & Manufacture of printed matter and recorded media & 1.7 & 0.2 & 14 & 0.0 & 0.1 \\
\hline 12 & $\begin{array}{l}\text { Manufacture of coke, refined petroleum products and nuclear } \\
\text { fuels }\end{array}$ & 23.1 & 0.3 & 8 & 1.0 & 12.9 \\
\hline 13 & Manufacture of chemicals, chemical products & 16.7 & 1.4 & 46 & 0.8 & 5.9 \\
\hline 14 & Manufacture of rubber and plastic products & 10.1 & 0.8 & 58 & 0.3 & 1.5 \\
\hline 15 & Manufacture of other non-metallic mineral products & 24.8 & 2.7 & 264 & 1.4 & 2.7 \\
\hline 16 & Manufacture of basic metals & 66.4 & 2.9 & 112 & 0.9 & 9.7 \\
\hline 17 & $\begin{array}{l}\text { Manufacture of fabricated metal products, except machinery } \\
\text { and equipment }\end{array}$ & 22.9 & 2.0 & 382 & 0.6 & 3.5 \\
\hline 18 & Manufacture of machinery and equipment n.e.c. & 0.2 & 0.0 & 2 & 0.0 & 0.1 \\
\hline 19 & Manufacture of office machinery and computers & 0.0 & 0.0 & 0 & 0.0 & 0.1 \\
\hline 20 & Manufacture of electrical machinery and apparatus n.e.c. & 10.4 & 1.0 & 57 & 0.1 & 3.4 \\
\hline 21 & $\begin{array}{l}\text { Manufacture of radio, television and communication } \\
\text { equipment and apparatus }\end{array}$ & 0.0 & 0.0 & 0 & 0.0 & 0.1 \\
\hline 22 & $\begin{array}{l}\text { Manufacture of medical, precision and optical instruments, } \\
\text { watches and clocks }\end{array}$ & 0.3 & 0.0 & 6 & 0.0 & 0.6 \\
\hline 23 & Manufacture of motor vehicles, trailers and semi-trailers & 1.1 & 0.1 & 4 & 0.0 & 0.4 \\
\hline 24 & Manufacture of other transport equipment & 0.2 & 0.0 & 3 & 0.0 & 0.4 \\
\hline 25 & Manufacture of furniture; other manufactured goods n.e.c. & 0.6 & 0.1 & 15 & 0.0 & 0.0 \\
\hline 26 & Recycling & 16.5 & 0.6 & 89 & 0.0 & 213.2 \\
\hline 27 & Electrical energy, gas, steam and hot water & 12.3 & 1.1 & 14 & 0.2 & 0.0 \\
\hline 28 & Collected and purified water, distribution services of water & 4.5 & 0.4 & 7 & 0.0 & 0.0 \\
\hline 29 & Construction & 348.6 & 57.7 & 3165 & 16.6 & 0.0 \\
\hline 30 & Wholesale and retail trade & 64.3 & 8.6 & 833 & 2.1 & 0.4 \\
\hline 31 & Hotels and restaurants & 3.8 & 0.3 & 33 & 0.1 & 0.1 \\
\hline 32 & Transport, storage and communication & 38.7 & 2.7 & 99 & 4.0 & 0.0 \\
\hline 33 & Financial intermediation & 9.5 & 2.3 & 35 & 0.5 & 0.2 \\
\hline 34 & Education services & 1.1 & 0.7 & 17 & 0.0 & 0.0 \\
\hline 35 & Health and social work services & 0.7 & 0.2 & 10 & 0.0 & 0.0 \\
\hline \multirow[t]{2}{*}{36} & Other services & 48.7 & 10.5 & 354 & 1.1 & 0.8 \\
\hline & TOTAL & 768.7 & 101.3 & 5867 & 34.9 & 260.3 \\
\hline
\end{tabular}

Source: Authors' calculations based on 2008 IZKA Izmir Input-Output Table. 1 TL $=0.55$ US\$ for 2012 
Appendix Table 2. Impact of Tourism Expenditures (million TL in 2012 prices or people/year for employment effects)

\begin{tabular}{|c|c|c|c|c|c|c|}
\hline & & $\begin{array}{l}\text { Impact on } \\
\text { Production } \\
\end{array}$ & $\begin{array}{l}\text { Impact on } \\
\text { Labor } \\
\text { Demand } \\
\end{array}$ & $\begin{array}{l}\text { Impact on } \\
\text { Labor } \\
\text { Income } \\
\end{array}$ & \begin{tabular}{|c} 
Impact on Net \\
Tax
\end{tabular} & $\begin{array}{l}\text { Impact on } \\
\text { Imports }\end{array}$ \\
\hline 1 & Agriculture, hunting and forestry & 68.8 & 5.2 & 835 & 11.6 & 7.7 \\
\hline 2 & Fishing & 3.6 & 0.3 & 37 & 0.1 & 0.0 \\
\hline 3 & Mining and quarrying & 43.7 & 5.6 & 155 & 6.4 & 2.4 \\
\hline 4 & Manufacture of food products and beverages & 43.9 & 3.7 & 281 & 2.2 & 4.0 \\
\hline 5 & Manufacture of tobacco products & 0.0 & 0.0 & 0 & 0.0 & 0.0 \\
\hline 6 & Manufacture of textiles and textile products & 0.8 & 0.1 & 9 & 0.1 & 0.2 \\
\hline 7 & Manufacture of wearing apparel; dressing and dyeing of fur & 1.1 & 0.1 & 19 & 0.1 & 0.1 \\
\hline 8 & $\begin{array}{l}\text { Tanning and dressing of leather; manufacture of luggage, } \\
\text { handbags, saddlery, harness and footwear }\end{array}$ & 0.3 & 0.0 & 3 & 0.0 & 0.1 \\
\hline 9 & $\begin{array}{l}\text { Manufacture of wood and products of wood and cork (except } \\
\text { furniture); articles of straw and plaiting materials }\end{array}$ & 0.7 & 0.1 & 11 & 0.0 & 0.2 \\
\hline 10 & Manufacture of pulp, paper and paper products & 4.8 & 0.5 & 26 & 0.1 & 1.9 \\
\hline 11 & Manufacture of printed matter and recorded media & 7.2 & 0.8 & 62 & 0.0 & 0.3 \\
\hline 12 & $\begin{array}{l}\text { Manufacture of coke, refined petroleum products and nuclear } \\
\text { fuels }\end{array}$ & 34.4 & 0.4 & 13 & 1.5 & 19.2 \\
\hline 13 & Manufacture of chemicals, chemical products & 37.3 & 3.1 & 103 & 1.7 & 13.1 \\
\hline 14 & Manufacture of rubber and plastic products & 9.2 & 0.7 & 53 & 0.3 & 1.4 \\
\hline 15 & Manufacture of other non-metallic mineral products & 5.6 & 0.6 & 60 & 0.3 & 0.6 \\
\hline 16 & Manufacture of basic metals & 17.4 & 0.8 & 29 & 0.2 & 2.5 \\
\hline 17 & $\begin{array}{l}\text { Manufacture of fabricated metal products, except machinery } \\
\text { and equipment }\end{array}$ & 5.4 & 0.5 & 89 & 0.1 & 0.8 \\
\hline 18 & Manufacture of machinery and equipment n.e.c. & 0.2 & 0.0 & 2 & 0.0 & 0.1 \\
\hline 19 & Manufacture of office machinery and computers & 0.1 & 0.0 & 0 & 0.0 & 0.3 \\
\hline 20 & Manufacture of electrical machinery and apparatus n.e.c. & 5.8 & 0.6 & 32 & 0.1 & 1.9 \\
\hline 21 & $\begin{array}{l}\text { Manufacture of radio, television and communication } \\
\text { equipment and apparatus }\end{array}$ & 0.1 & 0.0 & 0 & 0.0 & 0.1 \\
\hline 22 & $\begin{array}{l}\text { Manufacture of medical, precision and optical instruments, } \\
\text { watches and clocks }\end{array}$ & 0.6 & 0.1 & 10 & 0.0 & 1.1 \\
\hline 23 & Manufacture of motor vehicles, trailers and semi-trailers & 2.4 & 0.1 & 8 & 0.0 & 0.8 \\
\hline 24 & Manufacture of other transport equipment & 0.7 & 0.1 & 8 & 0.0 & 1.3 \\
\hline 25 & Manufacture of furniture; other manufactured goods n.e.c. & 5.7 & 0.6 & 131 & 0.1 & 0.3 \\
\hline 26 & Recycling & 4.7 & 0.2 & 26 & 0.0 & 61.2 \\
\hline 27 & Electrical energy, gas, steam and hot water & 112.8 & 10.0 & 133 & 1.4 & 0.0 \\
\hline 28 & Collected and purified water, distribution services of water & 45.1 & 4.4 & 73 & 0.3 & 0.0 \\
\hline 29 & Construction & 4.7 & 0.8 & 42 & 0.2 & 0.0 \\
\hline 30 & Wholesale and retail trade & 120.4 & 16.1 & 1560 & 4.0 & 0.8 \\
\hline 31 & Hotels and restaurants & 677.8 & 45.3 & 5910 & 20.4 & 22.9 \\
\hline 32 & Transport, storage and communication & 96.2 & 6.7 & 245 & 9.9 & 0.0 \\
\hline 33 & Financial intermediation & 17.7 & 4.3 & 65 & 1.0 & 0.3 \\
\hline 34 & Education services & 3.0 & 1.9 & 46 & 0.1 & 0.0 \\
\hline 35 & Health and social work services & 1.3 & 0.4 & 19 & 0.0 & 0.0 \\
\hline \multirow[t]{2}{*}{36} & Other services & 159.7 & 34.3 & 1162 & 3.5 & 2.6 \\
\hline & TOTAL & 1543.02 & 148.27 & 11258 & 65.79 & 148.17 \\
\hline
\end{tabular}

\footnotetext{
Source: Authors' calculations based on 2008 IZKA Izmir Input-Output Table. 1 TL $=0.55$ US\$ for 2012.
} 